\title{
Suppression of Powdery Mildew on Greenhouse-Grown Cucumber by Addition of Silicon to Hydroponic Nutrient Solution Is Inhibited at High Temperature
}

\author{
Andrew C. Schuerger, Senior Plant Pathologist, and William Hammer, Plant Pathologist, The Land, Epcot Center, \\ Lake Buena Vista, FL 32830
}

\begin{abstract}
Schuerger, A. C., and Hammer, W. 2003. Suppression of powdery mildew on greenhouse-grown cucumber by addition of silicon to hydroponic nutrient solution is inhibited at high temperature. Plant Dis. 87:177-185.

Silicon amendments to hydroponic nutrient solutions have been used successfully in Canada to suppress powdery mildew (PM) caused by Sphaerotheca fuliginea on cucumber (Cucumis sati$v u s)$. In contrast, preliminary trials in Florida greenhouses failed to achieve the level of disease suppression reported in the literature for Canadian studies. A series of greenhouse experiments were conducted in Florida to determine the factors involved in reducing the effectiveness of silicon amendments for PM suppression on cucumber. Three horticultural practices (cultivar, nutrient solution formula, and rooting medium) and two environmental factors (light intensity and temperature) were tested in combination with silicon amendments for their effects on the suppression of PM on cucumber. When plants were irrigated with a standard nutrient solution amended with potassium silicate at $0 \mathrm{mg} / \mathrm{liter}$, the cucumber $\mathrm{cv}$. Vetomil was found to be resistant and cvs. Corona, Cilla, Farbio, and Toska were found to be susceptible to PM. Susceptible cultivars irrigated with potassium silicate at 100,150 , or $200 \mathrm{mg} / \mathrm{liter}$ exhibited a slight but statistically significant reduction in PM over the course of a 49-day trial. Although PM in the cultivar trial was slightly lower in treatments with added silicon, disease suppression with silicon was not commercially useful because it failed to increase fruit yields. Nutrient solution formula, rooting medium, and light intensity had no effects on the levels of PM suppression, regardless of whether plants were irrigated with potassium silicate at 0 or $100 \mathrm{mg} / \mathrm{liter}$. Temperature was found to act in a synergistic manner with silicon. The greatest effect of temperature on $\mathrm{PM}$ suppression was observed at $20^{\circ} \mathrm{C}$ in which cucumber plants, irrigated with silicon at $100 \mathrm{mg} /$ liter, exhibited significant reductions in the numbers of PM colonies per leaf. Disease suppression by silicon was observed at 25 and $30^{\circ} \mathrm{C}$, but the magnitude of the disease suppression was significantly lower than when plants were maintained at $20^{\circ} \mathrm{C}$. The effect of temperature on PM suppression by silicon may explain the difference in results between previous experiments in Canada, where greenhouse temperatures averaged 20 to $25^{\circ} \mathrm{C}$, and the current study in Florida, where greenhouse temperatures averaged 24 to $32^{\circ} \mathrm{C}$.
\end{abstract}

Additional keywords: potassium silicate

Powdery mildew (PM) of greenhousegrown cucumber plants, caused by Sphaerotheca fuliginea (Schlechtend.:Fr.) Pollacci, can create devastating disease outbreaks that may result in dramatic reductions in fruit yield $(3,10)$. Although some resistant cultivars are available (10), greenhouse growers have pursued alternative methods of controlling PM on cucumber, including the use of traditional fungicides, compost extracts, plant extracts, salts and detergents, surfactants, oils, and biological control agents $(3,10)$. Silicon

Corresponding author: A. C. Schuerger

E-mail: schueac@kscems.ksc.nasa.gov

Current address of A. C. Schuerger: Dynamac Corporation, Life Sciences Support Contract, Mail Code DYN-3, Kennedy Space Center, FL 32899.

Accepted for publication 27 September 2002.

Publication no. D-2002-1211-01R

(C) 2003 The American Phytopathological Society also has been tested as a control agent for $\mathrm{PM}$ on greenhouse-grown cucumber in Canada with relatively good levels of success $(2,14,15,17)$.

Silicon is thought to play an important role in plant growth and development $(5,7,11)$. Silicon is the second most abundant element in soils, and can be found in soil solutions at concentrations between 0.1 and $0.6 \mathrm{mM}$ (7). Silicon concentrations in tissues of most plants range from trace amounts to approximately $1 \%$ of dry matter (7); however, some accumulator plant species can have tissue concentrations in the range of 6 to $10 \%$ of dry matter $(4,7)$. Silicon is readily absorbed by most plants in the form of $\mathrm{H}_{4} \mathrm{SiO}_{2}(7,11)$, and deposited in cell walls, cell lumens, and intercellular spaces as amorphous $\mathrm{SiO}_{2} \cdot n \mathrm{H}_{2} \mathrm{O}$ (7). However, the essentiality of silicon for plant growth and development is still under debate $(2,5,7,11,12,16)$. Several workers $(5,12,16)$ have demonstrated that, when silicon was absent from nutrient solutions, cucumber plants exhibited significant amounts of stunting, leaf curling, and chlorosis. The addition of silicon to nutrient solutions at concentrations of $100 \mathrm{mg} / \mathrm{liter}$, or greater, prevented these visual symptoms $(12,16)$. Others have noted that silicon added to nutrient solutions can decrease lodging and drooping of plants, mitigate chlorosis caused by low zinc, increase rigidity of mature leaves, increase chlorophyll content of leaves, improve growth rates, and increase the resistance of plants to fungus attack $(11,12)$.

The first report of suppressing PM on cucumber with silicon amendments was that of Wagner in 1940 (22). More recently, Menzies, Bélanger, and coworkers $(2,13-15,17,19)$ have studied the mechanisms of PM suppression in cucumber irrigated with nutrient solutions amended with silicon. In general, these workers found that silicon added to nutrient solutions at rates of $100 \mathrm{mg} / \mathrm{liter}$ or greater increased latent period, reduced the number of colonies per leaf, decreased colony area per leaf, and reduced the germination rates of conidia of $S$. fuliginea on cucumber plants grown in greenhouses $(2,13-$ 15,17). Rates of silicon application higher than $100 \mathrm{mg} /$ liter were found to have little added effect on suppressing PM on cucumber $(2,14)$.

Based on previous success with silicon for PM suppression $(2,5,13,14,15,17)$, we initiated a series of experiments in Florida to determine if silicon amendments could be used to achieve high levels of PM control on greenhouse-grown cucumber. We used the procedures of Menzies et al. (14) and Samuels et al. (17) for initial tests of PM suppression with silicon. A preliminary trial with 10 cucumber cultivars irrigated with nutrient solutions amended with potassium silicate at the rate of 100 $\mathrm{mg} /$ liter failed to demonstrate effective control of PM for silicon-amended treatments (A. C. Schuerger, unpublished). PM suppression was observed to be statistically lower on cucumber plants irrigated with silicon at 100 compared with $0 \mathrm{mg} / \mathrm{liter}$, but the PM suppression was of no practical value because yields of $\mathrm{Si}-$ and $\mathrm{Si}+$ plants were identical, and PM symptoms were only slightly lower in $\mathrm{Si}+$ treatments. No immediate explanation was obvious for the failure in the Florida trials to induce the high levels of control of PM on cucumber plants reported elsewhere $(2,5,13-15,17)$.

The primary objective in the current study was to determine if silicon amend- 
ments could be effective in the control of powdery mildew on greenhouse cucumber in Florida. Experiments were designed to compare three horticultural practices (cultivar, nutrient solution formula, and rooting medium) and two environmental factors (light intensity and temperature) that differed between published Canadian studies $(2,5,13-15,17)$ and the practices used in Florida (described below). A secondary objective of the current study was to determine the silicon levels in plant tissues grown in nutrient solutions with added silicon and compare them to levels found in commercially available cucumber. The results of these tests were expected to provide a baseline of natural silicon concentration in cucumber fruit available to the general public that could be compared with the silicon levels in greenhousegrown cucumber fruit produced with nutrient solutions amended with silicon.

\section{MATERIALS AND METHODS}

Preparation of inoculum. Cultures of the foliar pathogen, $S$. fuliginea, were maintained on cucumber plants (Cucumis sativus L., cv. Corona) growing in pots of silica sand and irrigated as required with a complete nutrient solution (Sol A; Table 1). Cultures of $S$. fuliginea were maintained in a separate greenhouse from the experimental plants discussed below. Twentyfour hours prior to harvesting conidia, the cucumber leaves were shaken vigorously in order to dislodge conidia of uncertain age and condition. Conidia were harvested just prior to inoculating experimental cucumber plants by gently brushing fresh colonies of PM into $20 \mathrm{ml}$ of Fluorinert FC-43 (3M Specialty Chemicals Division, St. Paul, MN). Conidia were counted in the Fluorinert and diluted to specific densities as described for each experiment. Inoculum was applied to individual leaves with an aerosol application device (Spra-Tool;
Crown, Inc., Woodstock, IL) in which spore suspensions were misted onto leaves for 1 or $2 \mathrm{~s}$. Tests confirmed that $1 \mathrm{ml}$ of Fluorinert could be applied to cucumber leaves during each 1-s burst. Preliminary tests demonstrated that inoculum of $S$. fuliginea could be applied reliably to leaves by this method resulting in uniform layers of spores (data not shown). Furthermore, leaves inoculated for $1 \mathrm{~s}$ with a spore suspension of 1,000 conidia per milliliter of Fluorinert developed approximately 100 colonies of PM after 10 days.

Experiment 1. Seed of cucumber cultivars (Cilla, Corona, Farbio, Toska, Cilla, and Vetomil) were germinated in $3-\mathrm{cm}$ rockwool cubes (Grodan, Hedehusene, Denmark). Rockwool growing slabs in polypropylene bags (Grodan) measuring 91 by 20 by $5 \mathrm{~cm}$ were arranged in four double rows with 15 rockwool slabs per row. Rockwool slabs were placed on white sheets of polypropylene in a $250-\mathrm{m}^{2}$ greenhouse. One 10-day-old seedling was transplanted into each rockwool slab. Cucumber plants were watered as required with a complete nutrient solution (Sol A) adjusted to a hydrogen ion concentration $(\mathrm{pH})$ of 6 and containing potassium silicate at 0,100 , 150 , or $200 \mathrm{mg} / \mathrm{liter}$. The silicon concentration in the source water for these experiments was measured at $10 \mathrm{mg} / \mathrm{liter}$ (Table 1). Therefore, the rates of potassium silicate products mixed into nutrient solutions were adjusted to accommodate the small amount of silicon found in the source water. Silicon was added to Sol A as potassium silicate $\left(20.7 \% \mathrm{SiO}_{2}\right.$; Kasil No. 1; PQ Corporation, Philadelphia, PA). The macronutrients and micronutrients were mixed from reagent grade salts obtained from Sigma-Aldrich (St. Louis, MO) and blended into a standard nutrient solution (Sol A, Table 1). Nutrients were delivered through an automatic injector system (model BVD-5; H. E. Anderson Co., Mus-

Table 1. Compositions of Sol A, Sol B, and source water ${ }^{2}$

\begin{tabular}{lccc}
\hline Element & Sol A & Sol B & Source water (mg/liter) \\
\hline Macronutrients $(\mathrm{mM})$ & & & \\
$\mathrm{N}$ & 10.0 & 13.0 & ND \\
$\mathrm{P}$ & 1.13 & 1.5 & 0.08 \\
$\mathrm{~K}$ & 5.36 & 7.0 & 0.8 \\
$\mathrm{Ca}$ & 3.74 & 3.5 & 30.0 \\
$\mathrm{Mg}$ & 1.65 & 1.0 & 7.0 \\
$\mathrm{~S}$ & 1.40 & 1.0 & $\mathrm{ND}$ \\
$\mathrm{Micronutrients}(\mu \mathrm{M})$ & & & \\
$\mathrm{Fe}$ & 44.8 & 18.0 & $\mathrm{ND}$ \\
$\mathrm{Mn}$ & 13.7 & 5.5 & $\mathrm{ND}$ \\
$\mathrm{B}$ & 27.8 & 46.0 & 10.0 \\
$\mathrm{Zn}$ & 3.1 & 1.5 & $\mathrm{ND}$ \\
$\mathrm{Cu}$ & 2.3 & 0.5 & 0.05 \\
$\mathrm{Mo}$ & 0.5 & 0.5 & $\mathrm{ND}$ \\
$\mathrm{Miscellaneous}$ & & & \\
$\mathrm{Si}$ & $\ldots$ & $\ldots$ & 10.0 \\
$\mathrm{HCO}$ & $\ldots$ & $\ldots$ & 95.0 \\
$\mathrm{Na}$ & $\ldots$ & $\ldots$ & 3.0 \\
$\mathrm{Cl}$ & $\ldots$ & & 8.0 \\
\hline
\end{tabular}

${ }^{\mathrm{z}}$ Sol A = standard nutrient solution mix; Sol B = Menzies nutrient solution mix described in Samuels et al. (17); ND = not detected. kogee, OK) with four 57-liter concentrate tanks containing $\mathrm{CaNO}_{3}$ and $\mathrm{Fe}$-Sequestrene 330 in tank 1 , the remaining macronutrients and micronutrients in tank 2 , potassium silicate in tank 3 , and $0.3 \mathrm{~N}$ $\mathrm{H}_{2} \mathrm{SO}_{4}$ in tank 4. Concentrates of nutrients were maintained in separate tanks to prevent the precipitation of concentrated salts. Silicon levels in the working nutrient solutions were checked every 7 days with a Hach Silica Test Kit (model Si-5, Hach Company, Loveland, $\mathrm{CO}$ ), and the nutrient proportioning meters recalibrated if the silicon concentrations drifted more than $5 \%$ from the desired set points.

Treatments were arranged in a completely randomized block design in which two blocks were used to determine if there was an effect of shading within the greenhouse. Block 1 was on the south side of the research greenhouse (which abutted a second greenhouse), and was slightly shaded compared with block 2 . Throughout the year, block 2 always was illuminated by full sunlight. Each block was composed of 60 rockwool slabs arranged in two double rows with 15 rockwool slabs per row. Treatments were further arranged in a split-plot design in which the silicon concentration was the main plot and the cultivars were the split-plot. Treatments consisted of four silicon levels and five cucumber cultivars (three replicates per treatment per block). After transplanting, the third and tenth leaves of plants were inoculated with conidia of $S$. fuliginea $(2,500$ conidia/ml $)$ on days 10 and 28 , respectively. Leaves in all experiments were selected for inoculation by counting the number of fully expanded true leaves up from the soil line.

Plants were rated for the severity of PM every 7 days after transplanting with the following disease rating system: $1=$ no PM on leaves; $2=1$ to $10 \mathrm{PM}$ colonies on each of one to two leaves; $3=11$ to $25 \mathrm{PM}$ colonies on each of three to five leaves or leaves with small coalescing colonies; $4=$ $>25$ PM colonies on each of six or more leaves or leaves with large coalescing colonies; and $5=$ leaves completely covered by PM, resulting in premature senescence. Plant height was measured every 7 days after transplanting for 28 days. Mature fruit were harvested and weighed three times per week from 21 to 49 days after transplanting. The experiment was conducted twice from May through October 1992 ( $n=12$ per treatment). Average day and night temperatures were collected in this and all subsequent experiments with handheld max-min mercury thermometers shielded from direct solar illumination.

Leaf and fruit tissues from 49-day-old cucumber (cv. Corona) plants irrigated with silicon at $0,100,150$, or $200 \mathrm{mg} / \mathrm{liter}$ were analyzed for silicon content. Leaves were randomly selected and prepared as described below. Cucumber fruit from 
experimental plots were collected and dissected into the following tissues: (i) fruit with periderm removed, (ii) excised periderm that was not washed, and (iii) excised periderm that was thoroughly washed in deionized water. Greenhouse and field cucumber fruit were purchased from local supermarkets in Orlando, FL, and separated into the following: (i) fruit with periderm removed and (ii) fruit with intact but washed periderm. Excised and unwashed periderm tissues from the commercially purchased cucumber fruit were not assayed. All tissues were oven dried at $70^{\circ} \mathrm{C}$ for 4 days, finely ground to pass a 60-mesh metal screen, and analyzed for silicon content at the University of California-Los Angeles (UCLA) Laboratory of Biomedical and Environmental Sciences.

Experiment 2. A second greenhouse experiment was designed to compare the effects of both nutrient solution composition and rooting medium on the effectiveness of silicon to suppress PM on cucumber. Ten-day-old Corona cucumber seedlings were transplanted into either rockwool growing slabs (as described above) or plastic bags containing $6 \mathrm{~kg}$ each of horticultural grade sawdust obtained from British Columbia, Canada (courtesy of $\mathrm{J}$. G. Menzies). The sawdust was composed of wood from Douglas Fir and Western Hemlock trees (14). A single seedling was transplanted into each rockwool slab or sawdust bag. Seedlings were irrigated as required with the nutrient injector systems described above. The first nutrient solution (Sol A) was identical to the nutrient solution used in experiment 1 (Table 1). The second nutrient solution ( $\mathrm{Sol} \mathrm{B}$ ) was that of Menzies et al. (14; Table 1). Both Sol A and Sol B were adjusted to $\mathrm{pH} 6$ and applied as added silicon at either 0 or 100 $\mathrm{mg} / \mathrm{liter}$. Silicon was added as potassium silicate supplied as Kasil No. 1 (20.7\% $\left.\mathrm{SiO}_{2}\right)$ to Sol A or as Kasil No. 6 (26.3\% $\mathrm{SiO}_{2}$ ) to Sol B. Both Kasil products were obtained from the PQ Corporation.

Treatments were arranged in a completely randomized block design in which the two blocks separated the partly shaded and full-sunlight portions of the research greenhouse (as described for experiment 1). Treatments were further divided among the various rockwool slabs in a split-split plot design in which the silicon concentration was the main plot, the choice between Sol A or Sol B was the split plot, and the choice between rockwool or sawdust rooting media was the split-split plot. There were three plants per treatment per block ( $n=18$ for the overall experiment).

Second and third fully expanded leaves were inoculated on 14 and 18 days, respectively, after transplanting. Second fully expanded leaves were inoculated with 1,000 conidia/ml/leaf. These leaves were maintained for 10 days, then harvested to measure leaf area, number of PM colonies per leaf, and total area of PM colonies per leaf. The percent leaf area covered by PM then was calculated for each leaf. Leaf areas were measured directly with a leaf area meter (model LI-3000A, LI-COR Portable Leaf Area Meter; LI-COR, Inc., Lincoln, NE). The areas of PM colonies per leaf were measured by placing transparent sheets of plastic over cucumber leaves and tracing the outlines of PM colonies with black indelible ink markers. The encircled PM colonies were shaded black with indelible ink, and then shaded areas measured with the leaf area meter. Third fully expanded leaves were inoculated by applying $1 \mathrm{ml}$ of Fluorinert containing 6,000 conidia $/ \mathrm{ml}$. The inoculated third fully expanded leaves were left on the cucumber plants for the duration of the experiment.

Plants were maintained in the research greenhouse for 49 days after transplanting, then harvested. Plant heights were measured at 28 days after transplanting. Mature fruit were harvested and weighed three times per week from 21 to 49 days after transplanting. The experiment was conducted three times from December 1992 through June 1993 ( $n=18$ per treatment).

Experiment 3. The effect of shading on the effectiveness of silicon to suppress PM was tested in order to determine if differ- ences in light intensities between trials in Canada and Florida could explain the lack of control of PM by silicon in Florida. Photosynthetic active radiation (PAR; 400 to $700 \mathrm{~nm}$ ) measurements under the shade screens were collected with a handheld light sensor (model LI-250; LI-COR). Tenday-old Corona cucumber seedlings were germinated in $3-\mathrm{cm}$ rockwool cubes, transplanted into $19-\mathrm{cm}$ pots containing pasteurized silica sand, then placed on greenhouse benches under $0,30,50$, or $70 \%$ shade screens. Shade screens were composed of woven polypropylene black plastic (A. H. Hummert, Inc, Apopka, FL). The nutrient irrigation systems used in experiments 1 and 2 were modified to deliver nutrient Sol A, at $\mathrm{pH} \mathrm{6,} \mathrm{to} \mathrm{plants} \mathrm{with} \mathrm{sili-}$ con (supplied as Kasil No. 1) at 0 or 100 $\mathrm{mg} /$ liter through a drip irrigation system. Seedlings were irrigated as required to optimize growth and development.

Treatments were arranged in a completely randomized split-plot design in which the main plot was shading and the split-plot was silicon concentration. Each shading level was created on separate 1.5by-2.4-m greenhouse benches. Shading levels were randomly assigned to one of four greenhouse benches and the order of the benches was randomized for each repe-

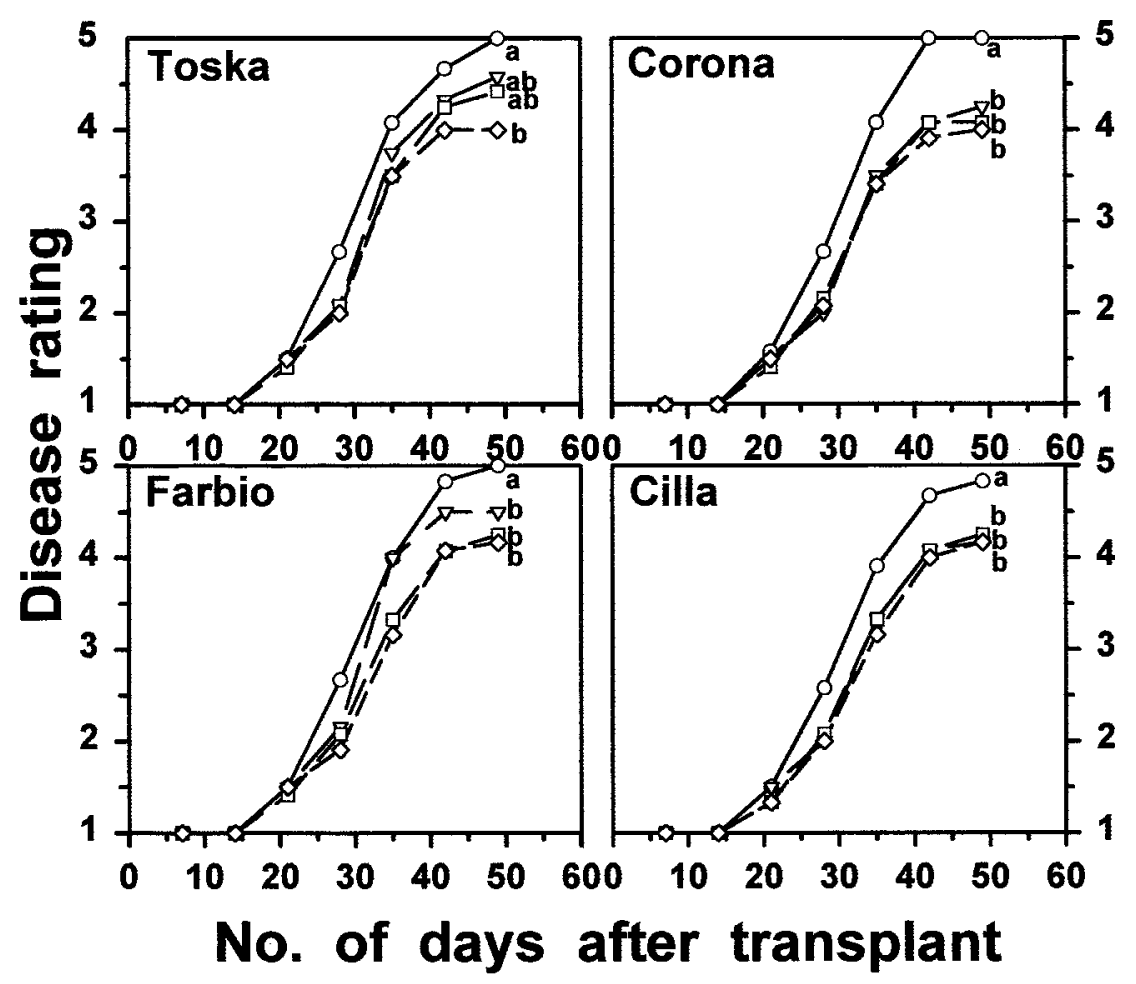

Fig. 1. Disease progress curves for the development of the powdery mildew (PM) pathogen, Sphaerotheca fuliginea, on cucumber (Cucumis sativus) cvs. Cilla, Corona, Farbio, and Toska. Cucumber cv. Vetomil was highly resistant to PM and, thus, exhibited a disease rating of zero throughout the experiment (data not shown). Lines represent silicon treatments of potassium silicate at $0(O), 100(\nabla), 150(\square)$, or $200(\diamond) \mathrm{mg} /$ liter. Data were analyzed separately for each sample day and cultivar with nonparametric Kruskal-Wallis tests. Different letters on day 49 represent significant differences among the four silicon treatments for specific cultivars $(P \leq 0.01 ; n=12)$; similar results were obtained for Days 28, 35, and 42. No significant differences in PM ratings for silicon amendments were observed on days 7, 14, or 21 for any cultivar. Standard error bars of means have not been included for clarity. 
tition of the experiment. Ten days after transplanting, second fully expanded leaves were sprayed with $1 \mathrm{ml}$ of Fluorinert containing 1,000 conidia/ml. Ten days after inoculation, inoculated leaves were harvested and leaf area, number of PM colonies per leaf, and area of PM colonies on inoculated leaves were recorded. After inoculated leaves were harvested, two randomly selected leaves from each plant were prepared as previously described and sent to the UCLA Laboratory of Biomedimining silicon content. The experiment cal and Environmental Sciences for deter-

was conducted three times from June through September $1993(n=15)$.

Experiment 4. To determine the effects of temperature on suppression of PM by silicon, 14-day-old Corona cucumber plants were transplanted into $15-\mathrm{cm}$ pots containing pasteurized silica sand and placed in plant growth chambers (model M-12; Environmental Growth Chambers, Chagrin Falls, OH). Temperatures were maintained at 20,25 , or $30^{\circ} \mathrm{C}$ under $12-\mathrm{h}$ diurnal photoperiods. Plants were grown under a PAR of 250 to $275 \mu \mathrm{mol} \mathrm{m} \mathrm{m}^{-2} \mathrm{~s}^{-1}$ supplied by a mixture of cool-white

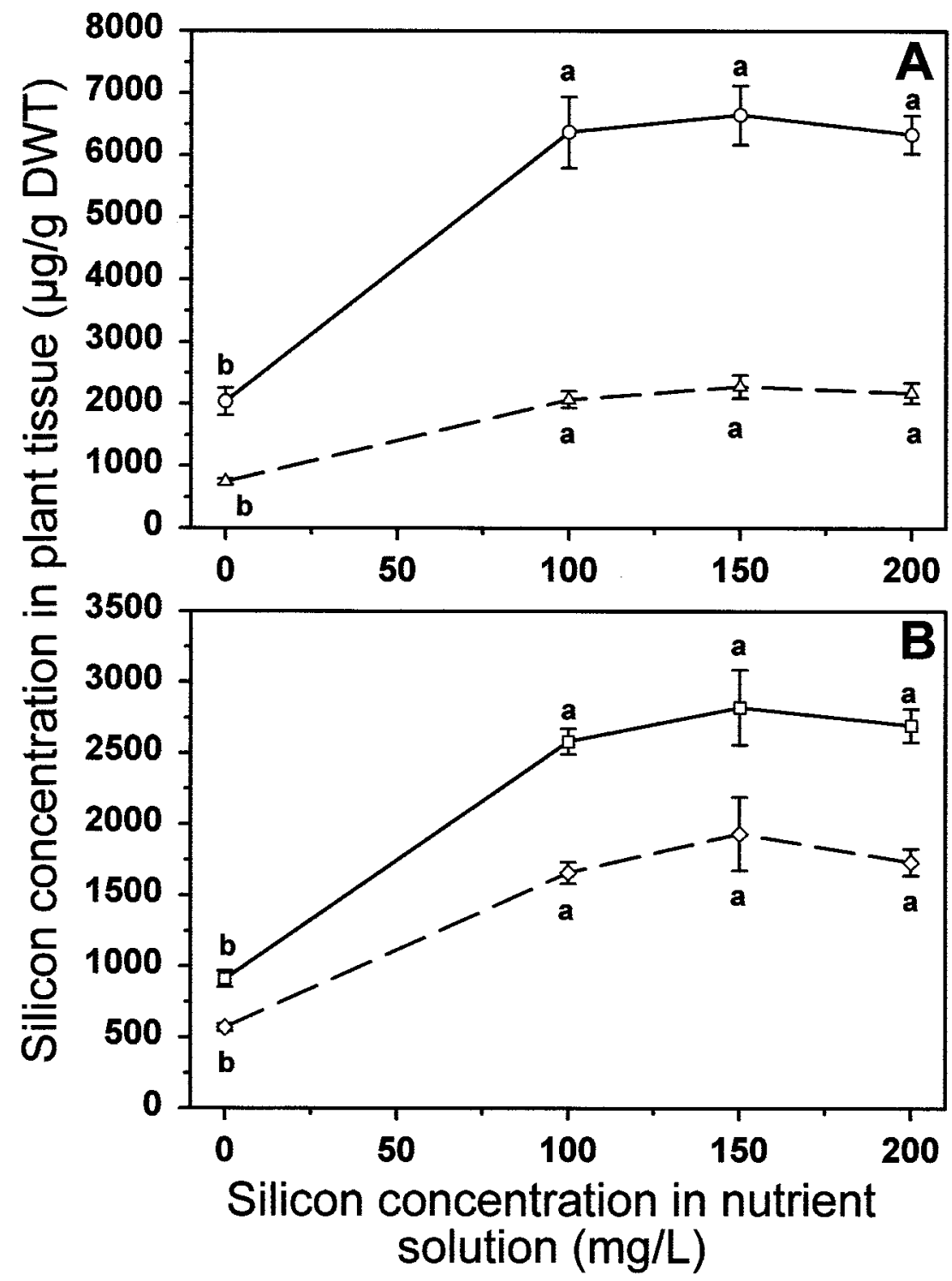

Fig. 2. Effects of silicon concentrations in nutrient solutions on silicon levels in cucumber (Cucumis sativus, cv. Corona) tissues. A, The silicon concentrations of leaves (O) were significantly higher than the measured silicon concentrations of fruit in which periderm tissues were removed $(\Delta)$. B, Washing excised periderm tissues $(\diamond)$ significantly reduced the amount of silicon present compared with unwashed periderm tissues $(\square)$. Data were analyzed with linear and quadratic regression analyses (PROC REG or PROC RSREG, respectively) and protected least squares mean separation tests (PROC GLM). All responses were described best by quadratic models, and different letters for individual curves indicate significant differences among silicon treatments $(P \leq 0.05 ; n=12)$; data were log-transformed prior to running protected mean separation tests. Data in the figures are detransformed means, and standard error bars are presented for each mean. [Leaves: $y=2,060+63 x$ $-0.209 x^{2} ; P<0.0001 ; r^{2}=0.748$. Fruit: $y=751+19 x-0.61 x^{2} ; P<0.0001 ; r^{2}=0.731$. Unwashed periderm: $y=911+24 x-0.078 x^{2} ; P<0.0001 ; r^{2}=0.748$. Washed periderm: $y=561+17 x-$ $0.055 x^{2} ; P<0.0001 ; r^{2}=0.661$.] fluorescent and incandescent lamps. The vapor pressure deficits were maintained for each temperature at $8 \mathrm{~mm}$ of $\mathrm{Hg}(54,66$, or $75 \%$ relative humidity for 20,25 , or $30^{\circ} \mathrm{C}$, respectively). Seedlings were manually watered once daily with nutrient solution Sol A (Table 1), at pH 6, containing silicon (Kasil No. 1) at either 0 or $100 \mathrm{mg} / \mathrm{liter}$.

Ten days after transplanting, second fully expanded leaves were each inoculated with $1 \mathrm{ml}$ of Fluorinert containing 1,000 conidia/ml. Treatments were arranged in a completely randomized split-plot design with five plants per treatment. The main plot was temperature and the split-plot was silicon concentration. Temperature treatments were randomly assigned to one of three plant growth chambers for each repetition of the experiment. Ten days after inoculation, leaf areas, numbers of PM colonies per leaf, and total PM area per leaf were recorded. Two randomly selected leaves from each plant were prepared as previously described and sent to the UCLA Laboratory of Biomedical and Environmental Sciences for determining silicon content. The experiment was conducted three times from February through April $1993(n=15)$

Statistical analyses. Statistical analyses were conducted with a PC-based Statistical Analysis System (SAS Institute, Inc., Cary, NC). Experiments 1 and 2 used randomized complete block designs in which plants were blocked for lighting effects within the research greenhouse. In experiment 1 , disease ratings for each sample date were analyzed by repeated-measures nonparametric Kruskal-Wallis procedures. Silicon concentrations in leaf and fruit tissues in experiment 1 were analyzed with linear or quadratic regression models (PROC REG or PROC RSREG, respectively). In experiment 2 , the effects of silicon concentration, nutrient solution, and rooting medium on various plant and disease parameters were analyzed by analysis of variance and protected Fisher's least significant difference tests with PROC GLM. Data from experiments 3 and 4 were analyzed first with orthogonal polynomial contrast analyses (CONTRAST statements within PROC GLM), and then linear or quadratic regression models (PROC REG or PROC RSREG) were tested for significant terms. Unless otherwise stated, significance was accepted at $P \leq 0.05$.

\section{RESULTS}

Experiment 1. Cucumber cv. Vetomil was strongly resistant to PM, exhibiting no symptoms or signs of the pathogen over the course of the entire 49-day experiment (data not shown). The disease progress curves for PM on cucumber cvs. Toska, Corona, Farbio, and Cilla illustrate that PM development on all four susceptible cultivars followed similar patterns (Fig. 1). First, symptoms of PM were observed on susceptible cultivars from 5 to 7 days after 
plants were inoculated (i.e., 15 to 17 days after transplanting); thus, disease ratings in Figure 1 for 7 and 14 days were zero. Second, the disease ratings for PM on cucumber plants irrigated with silicon at 100 , 150 , or $200 \mathrm{mg} / \mathrm{liter}$ were very similar among the four susceptible cultivars and among the three $\mathrm{Si}+$ treatments (Fig. 1). The disease ratings for susceptible cultivars irrigated with silicon generally were lower than for those plants irrigated with the same nutrient solution (Sol A) that contained no added silicon. Disease ratings for $\mathrm{Si}+$ treated plants susceptible to $\mathrm{PM}$ were between 4.0 and 4.5 on day 49 , and cucumber plants irrigated with Sol A without added silicon exhibited disease ratings between 4.9 (cv. Cilla) and 5.0 (cvs. Toska, Corona, and Farbio). No block effects were observed for plant disease ratings for cucumber cvs. Toska, Corona, Farbio, and Cilla $(P>0.10)$.

Horticultural measurements of all five cucumber cultivars indicated that plant height at 28 days $(2.2 \pm 0.45 \mathrm{~m})$, total numbers of fruit harvested $(14 \pm 2.5)$, and total fruit weights $(5.9 \pm 1.1 \mathrm{~kg})$ were similar among all cucumber cultivars independent of the concentrations of silicon added to nutrient solutions $(P>0.05$; data not shown). In addition, cucumber plants irrigated with silicon at 100,150 , or 200 $\mathrm{mg} /$ liter were morphologically identical to their respective control plants irrigated with added silicon at $0 \mathrm{mg} / \mathrm{liter}$. The only observed difference in $\mathrm{Si}+$ compared with $\mathrm{Si}$ - treated plants was the observation of white powdery secretions near trichome bases on periderm tissues of $\mathrm{Si}+$ treated cucumber fruit. Block effects were not observed for plant biometric measurements $(P>0.10)$.

Leaf and fruit tissues harvested on day 49 from Corona cucumber plants irrigated with silicon at $0,100,150$, or $200 \mathrm{mg} / \mathrm{liter}$ were analyzed for silicon. Silicon content was significantly higher in all tissues of $\mathrm{Si}+$ treated plants compared with $\mathrm{Si}-$ treated plants $(P<0.0001$; Fig. 2). However, the concentrations of silicon in these tissues were similar among treatments irrigated with silicon at 100,150 , or 200 $\mathrm{mg} /$ liter $(P>0.10)$. In plants irrigated with silicon at $\geq 100 \mathrm{mg} / \mathrm{liter}$, the average concentrations of silicon in leaves, unwashed periderm tissues, washed periderm tissues, and fruit tissues without periderm were $6,200,2,700,1,700$, and $2,100 \mu \mathrm{g} / \mathrm{g}$, respectively, on a dry weight basis (Fig. 2). In $\mathrm{Si}+$ treated plants, leaves had the highest concentrations of silicon and washed periderm tissues had the lowest concentrations of silicon. Furthermore, silicon residues on the surfaces of periderm tissues were significantly reduced by short periods of vigorous washing under a stream of deionized water.

The silicon concentrations of cucumber fruit varied widely in produce purchased at local supermarkets in the Orlando, FL area. In field-grown cucumbers, mean concentrations of silicon in fruit tissues without periderm and in washed periderm tissues were $1,678 \mu \mathrm{g} / \mathrm{g}$ dry weight (range: 602 to 2,533 ) and $520 \mu \mathrm{g} / \mathrm{g}$ dry weight (range: 353 to 1,861), respectively. In greenhouse-grown cucumber, fruit tissues without periderm and washed periderm tissues were $967 \mu \mathrm{g} / \mathrm{g}$ dry weight (range: 216 to 1,195$)$ and $418 \mu \mathrm{g} / \mathrm{g}$ dry weight (range: 256 to 793 ) for silicon, respectively.

Experiment 2. The number of PM colonies per leaf, area of PM colonies per inoculated leaf, and percent of leaf area covered by PM were similar among treatments in which Sol A and Sol B were compared $(P>0.27)$ and in which rockwool and sawdust were compared $(P>0.08)$ (Table $2)$. In contrast, symptoms were always significantly lower in plants irrigated with silicon at $100 \mathrm{mg} /$ liter versus plants irrigated with silicon at $0 \mathrm{mg} / \mathrm{liter}(P<$ 0.0001 ) (Table 2). Therefore, nutrient solution formula and rooting medium did not have any added effect on suppressing PM alone or in combination with silicon added to nutrient solutions. Block effects were not observed for the number of PM colonies per leaf, area of PM colonies per inoculated leaf, or percent of leaf area covered by PM $(P>0.33)$.

Table 3. Effects of silicon concentration, nutrient solution formula, and rooting medium on growth of cucumber (Cucumis sativus, cv. Corona) plants ${ }^{\mathrm{x}}$

\begin{tabular}{lccccc}
\hline $\begin{array}{l}\text { Silicon level } \\
\left.\text { (mg liter }^{-1}\right)\end{array}$ & $\begin{array}{c}\text { Nutrient } \\
\text { solution }^{\mathbf{y}}\end{array}$ & $\begin{array}{c}\text { Rooting } \\
\text { medium }^{\mathbf{z}}\end{array}$ & $\begin{array}{c}\text { Plant height } \\
(\mathbf{m})\end{array}$ & $\begin{array}{c}\text { Harvested fruit } \\
\text { weight per plant }(\mathbf{k g})\end{array}$ & $\begin{array}{c}\text { No. of harvested } \\
\text { fruit per plant }^{2}\end{array}$ \\
\hline 0 & Sol A & RW & $1.90 \mathrm{a}$ & $6.59 \mathrm{a}$ & $12.7 \mathrm{a}$ \\
& & SD & $1.91 \mathrm{a}$ & $6.20 \mathrm{a}$ & $11.9 \mathrm{a}$ \\
& Sol B & RW & $1.92 \mathrm{a}$ & $6.83 \mathrm{a}$ & $13.3 \mathrm{a}$ \\
100 & & SD & $1.99 \mathrm{a}$ & $6.38 \mathrm{a}$ & $12.9 \mathrm{a}$ \\
& Sol A & RW & $1.93 \mathrm{a}$ & $6.84 \mathrm{a}$ & $13.1 \mathrm{a}$ \\
& & SD & $1.95 \mathrm{a}$ & $6.43 \mathrm{a}$ & $12.9 \mathrm{a}$ \\
& \multirow{2}{*}{ Sol B } & RW & $1.93 \mathrm{a}$ & $6.05 \mathrm{a}$ & $11.9 \mathrm{a}$ \\
& & SD & $1.98 \mathrm{a}$ & $6.59 \mathrm{a}$ & $13.2 \mathrm{a}$ \\
\hline
\end{tabular}

${ }^{x}$ Data were not transformed prior to analysis. Treatments in columns followed by the same letter were not significantly different based on analysis of variance and protected Fisher's least significant difference tests $(P \leq 0.05 ; n=18)$. All model effects for plant height, harvested fruit per plant, and number of harvested fruit per plant were not significant $(P>0.28)$. Block effects were not observed for any parameters tested $(P>0.08)$.

${ }^{\mathrm{y}} \mathrm{Sol} \mathrm{A}=$ standard nutrient solution mix and Sol B $=$ Menzies nutrient solution mix described by Samuels et al. (17).

${ }^{\mathrm{z}} \mathrm{RW}=$ rockwool; $\mathrm{SD}=$ sawdust obtained from J. G. Menzies, Canada.

Table 2. Effects of silicon concentration, nutrient solution formula, and rooting medium on the development of Sphaerotheca fuliginea (PM) on cucumber (Cucumis sativus, cv. Corona) plants ${ }^{\mathrm{v}}$

\begin{tabular}{|c|c|c|c|c|c|c|}
\hline $\begin{array}{l}\text { Silicon level } \\
\left(\text { mg liter }^{-1}\right)\end{array}$ & $\begin{array}{l}\text { Nutrient } \\
\text { solution }^{w}\end{array}$ & $\begin{array}{l}\text { Rooting } \\
\text { medium }^{\mathrm{x}}\end{array}$ & $\begin{array}{l}\text { Areas of inoculated } \\
\text { leaves }\left(\mathrm{cm}^{2}\right)^{y}\end{array}$ & $\begin{array}{l}\text { No. of PM colonies per } \\
\text { inoculated leaf }\end{array}$ & $\begin{array}{l}\text { Area of PM colonies per } \\
\text { inoculated leaf }\left(\mathrm{cm}^{2}\right)^{\mathrm{y}}\end{array}$ & $\begin{array}{l}\text { Percent leaf area } \\
\text { covered by } \mathbf{P M}^{\mathbf{z}}\end{array}$ \\
\hline \multirow[t]{4}{*}{0} & Sol A & RW & $660 \mathrm{a}$ & $132 \mathrm{a}$ & $39.4 \mathrm{a}$ & $5.6 \mathrm{a}$ \\
\hline & & SD & $655 \mathrm{a}$ & $135 \mathrm{a}$ & $40.9 \mathrm{a}$ & $5.7 \mathrm{a}$ \\
\hline & Sol B & RW & $702 \mathrm{a}$ & $128 \mathrm{a}$ & $35.3 \mathrm{a}$ & $4.6 \mathrm{a}$ \\
\hline & & SD & $719 a$ & $136 \mathrm{a}$ & $40.0 \mathrm{a}$ & $5.1 \mathrm{a}$ \\
\hline \multirow[t]{4}{*}{100} & Sol A & RW & $663 \mathrm{a}$ & $65 \mathrm{~b}$ & $16.8 \mathrm{~b}$ & $2.5 \mathrm{~b}$ \\
\hline & & SD & $652 \mathrm{a}$ & $76 \mathrm{~b}$ & $19.8 \mathrm{~b}$ & $2.9 \mathrm{~b}$ \\
\hline & Sol B & RW & $674 \mathrm{a}$ & $68 \mathrm{~b}$ & $17.1 \mathrm{~b}$ & $2.6 \mathrm{~b}$ \\
\hline & & SD & $662 \mathrm{a}$ & $72 \mathrm{~b}$ & $18.1 \mathrm{~b}$ & $2.7 \mathrm{~b}$ \\
\hline
\end{tabular}

${ }^{\mathrm{v}}$ Treatments in columns followed by the same letter were not significantly different based on analysis of variance and protected Fisher's least-significant difference tests $(P \leq 0.05 ; n=18)$. For the number of PM colonies per leaf, area of PM per inoculated leaf, and percent leaf area covered by PM, the main model effects of silicon on PM suppression were significant $(P<0.0001)$, the split-plot effects of nutrient solution formula were not significant $(P$ $>0.27)$, and the split-split plot effects of rooting medium were not significant $(P>0.08)$. All model effects for leaf area were not significant $(P>0.16)$. Block effects were not observed for any parameters tested $(P>0.33)$.

${ }^{\mathrm{w}}$ Sol A = standard nutrient solution mix; Sol B = Menzies nutrient solution mix described by Samuels et al. (17).

${ }^{x} \mathrm{RW}=$ rockwool; $\mathrm{SD}=$ sawdust obtained from J. G. Menzies, Canada.

y Data were square-root transformed prior to analysis to induce homogeneity of variances.

${ }^{\mathrm{z}}$ Data were not transformed prior to analysis. 
Differences also were not observed among treatments for the measured plant biometric parameters $(P>0.16$; Tables 2 and 3). All treatments were similar for areas of inoculated leaves $(P>0.16$; Table 2$)$ and for plant height at 28 days, harvested fruit weight per plant, and number of harvested fruit per plant $(P>$ 0.28; Table 3). Thus, although PM disease was reduced slightly by the addition of silicon to the nutrient solutions, disease suppression did not contribute to an increase in growth or yield per plant. Block effects were not observed for plant biometric measurements $(P$ $>0.08$ ).

Experiment 3. Measurements of PAR for the research greenhouses used in the

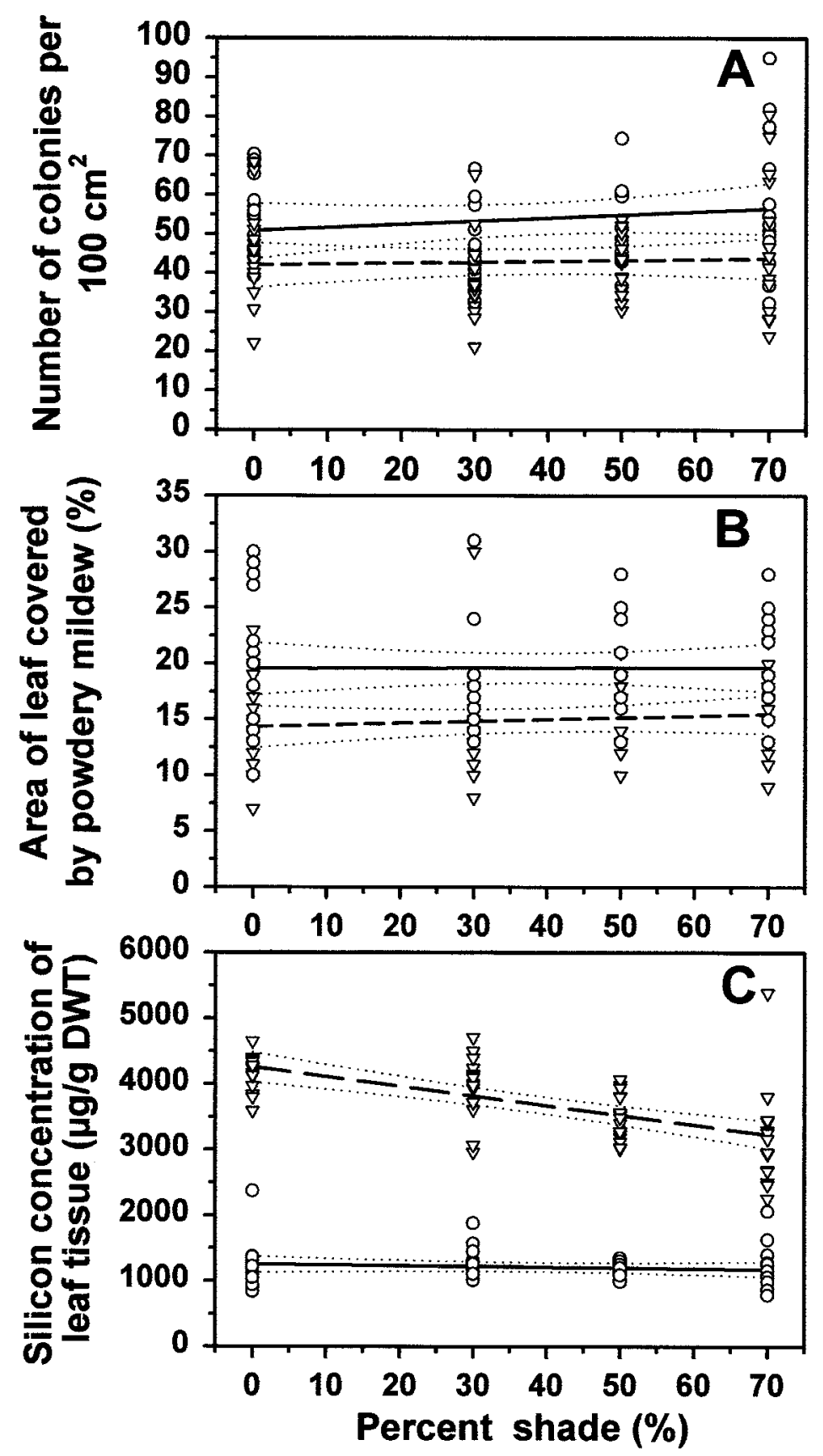

Fig. 3. Effects of shading on the effectiveness of silicon amendments in suppressing powdery mildew (PM) caused by Sphaerotheca fuliginea on cucumber (Cucumis sativus, cv. Corona) plants. Data were analyzed with orthogonal polynomial contrast (CONTRAST statements in PROC GLM) and linear regression models (PROC REG). No effects were observed for increasing levels of shading on $\mathbf{A}$, the number of PM colonies per leaf $(P>0.29)$ or on $\mathbf{B}$, the area covered by PM per leaf $(P>0.44)$. C, In contrast, silicon concentrations in cucumber leaves irrigated with potassium silicate at $100 \mathrm{mg} /$ liter were found to decrease as shading increased $(P<0.0001)$, but remained stable among all shading treatments for $\mathrm{Si}-$ treated plants $(P>0.43)$. For $\mathbf{A}$ and $\mathbf{B}, \mathrm{Si}+$ treated plants $(\nabla$; dashed lines) exhibited higher levels of measured responses than $\mathrm{Si}-$ treated plants $(\mathrm{O}$; solid lines) $(P \leq 0.05)$. C, The decrease in silicon concentration in cucumber leaves in $\mathrm{Si}+$ treated plants was described best by a linear model $\left(y=4,256-15 x ; P<0.01 ; r^{2}=0.370\right)$. $[n=15 ; 95 \%$ confidence intervals are given for each plot.] current study ranged from $900 \mu \mathrm{mol} \mathrm{m} \mathrm{m}^{-2} \mathrm{~s}$ ${ }^{1}$ in the winter to $1,800 \mu \mathrm{mol} \mathrm{m} \mathrm{m}^{-2} \mathrm{~s}^{-1}$ in the summer under clear-sky sunny conditions and recorded at 12:00 P.M. local time. The PAR handheld meter was used to confirm that the shade screens rated at 30,50 , and $70 \%$ shading were accurately reducing the overall light intensities under each shade material. Specific daily averages of light intensities during the shade experiments were not collected.

Lower light intensities created by increasing levels of shade failed to alter the suppressive qualities of silicon on PM on cucumber plants (Fig. 3). Shading had no effect on either the number of PM colonies $(P=0.29)$ or the total area of PM per inoculated leaf $(P=0.44)$. In both cases, the slopes of the regression lines were not different from zero, indicating no change in $\mathrm{PM}$ as shading was increased from 0 to $70 \%$. The addition of silicon to the nutrient solution decreased the number of PM colonies per leaf and total area of PM per inoculated leaf by 20 to $30 \%(P \leq 0.05)$ (Fig. 3A and B). Increased levels of shading on cucumber plants reduced the concentration of silicon measured in leaf tissues for the $\mathrm{Si}+$ treatment $(P<0.001)$ but not for the $\mathrm{Si}-$ treatment $(P=0.43)$ (Fig. $3 \mathrm{C})$. Thus, although the silicon concentration in cucumber leaves decreased 25 to $30 \%$ as shading increased from 0 to $70 \%$, no changes in the suppression of PM by silicon were observed as shading was increased.

Experiment 4. Changes in temperature had a dramatic effect on the suppression of $\mathrm{PM}$ on $\mathrm{Si}+$ treated plants. At $20^{\circ} \mathrm{C}$, the average number of PM colonies per inoculated leaf was $80 \%$ lower on $\mathrm{Si}+$ treated, compared with $\mathrm{Si}-$ treated, plants $(P<$ 0.0001 ; Fig. 4A). In contrast, at 25 and $30^{\circ} \mathrm{C}$, the average numbers of PM colonies per leaf were only 46 and 33\% lower, respectively, on $\mathrm{Si}+$ treated, compared with $\mathrm{Si}-$ treated, plants. The number of colonies per leaf versus temperature for $\mathrm{Si}$ - treated plants was fit best by a linear model with the slope not significantly different from zero $(P=0.91)$. The number of colonies per leaf versus temperature for $\mathrm{Si}+$ treated plants was fit best by a quadratic model $(P$ $=0.011)$. There was a significant interaction observed between silicon and temperature $(P=0.023)$ for the number of PM colonies per leaf (Fig. 4A). Thus, the difference between the number of PM colonies per leaf observed on $\mathrm{Si}+$ treated plants was greatest at $20^{\circ} \mathrm{C}$, and decreased at higher temperatures. However, the effects of temperature on the total area of PM per inoculated leaf were more complex than the effects of temperature on the number of PM colonies per leaf. First, both $\mathrm{Si}-$ and $\mathrm{Si}+$ irrigated plants exhibited changes in areas of PM per leaf due to temperature that were best described by quadratic models $(P<0.0001$; Fig. 4B $)$. The total areas of PM per inoculated leaf 
for both $\mathrm{Si}-$ or $\mathrm{Si}+$ irrigated plants were highest at $25^{\circ} \mathrm{C}$ and decreased as temperatures either were decreased to $20^{\circ} \mathrm{C}$ or increased to $30^{\circ} \mathrm{C}$. Second, a silicontemperature interaction was observed $(P=$ 0.05 ) in which the colony areas were similar for both $\mathrm{Si}-$ and $\mathrm{Si}+$ treated plants at $30^{\circ} \mathrm{C}$ and different at 20 or $25^{\circ} \mathrm{C}$.

The concentration of silicon in cucumber leaves for both the $\mathrm{Si}-$ and $\mathrm{Si}+$ treatments increased slightly as temperature increased from 20 to $30^{\circ} \mathrm{C}$ (Fig. 4C). The effects of increasing temperature on silicon concentrations in cucumber leaves were nearly identical for the plants irrigated with silicon at 0 or $100 \mathrm{mg} / \mathrm{liter}$. These responses were described best by linear models (Fig. 4C) in which silicon-temperature interactions were not observed $(P$ $>0.39$ ).

\section{DISCUSSION}

The primary objective of the current study was to determine why silicon amendments to hydroponic nutrient solutions failed to suppress PM on greenhouse cucumber in Florida, when similar silicon concentrations in Canada $(13-15,19)$ had significantly reduced the severity of PM on cucumber. Of the parameters tested, cultivar and temperature had significant effects on the suppression of PM, and nutrient solution formula, rooting medium, and light intensity had no observable effects on the suppression of PM. However, cucumber cv. Vetomil was the only cultivar that exhibited resistance to PM, and this resistance was observed independent of whether plants were irrigated with $\mathrm{Si}+$ or $\mathrm{Si}-$ treated nutrient solutions. Symptoms and disease ratings for all four susceptible cultivars irrigated with $\mathrm{Si}+$ or $\mathrm{Si}-$ treated nutrient solutions were similar over the course of experiment 1. Although cv. Corona was used in both the Canadian studies $(13-15,19)$ and the current study, the level of PM suppression on Corona cucumber induced by silicon in Canada was clearly superior to the results observed in Florida. Based on these results, we conclude that cultivar, nutrient solution, rooting medium, and light intensity were not factors in the lower levels of PM suppression by silicon in greenhousegrown cucumber in Florida.

Temperature, in combination with silicon, was found to alter PM suppression on cucumber leaves. The greatest effect of temperature on PM suppression was observed at $20^{\circ} \mathrm{C}$, in which cucumber plants irrigated with silicon at $100 \mathrm{mg} /$ liter exhibited significant reductions in the number of PM colonies per leaf. The differences in the number of PM colonies per leaf between the $\mathrm{Si}-$ and $\mathrm{Si}+$ treatments decreased at 25 and $30^{\circ} \mathrm{C}$, although the number of $\mathrm{PM}$ colonies on $\mathrm{Si}+$ treated plants remained significantly lower than on $\mathrm{Si}-$ treated plants. To our knowledge, this is the first report in which temperature has been shown to alter the effectiveness of silicon amendments for PM suppression of cucumber in hydroponic nutrient solutions. Menzies et al. (14) reported that tempera- tures in Canadian greenhouses ranged between 20 and $25^{\circ} \mathrm{C}$ during the year, and the range of temperatures in the current study were 24 to $27^{\circ} \mathrm{C}$ in the winter and 26

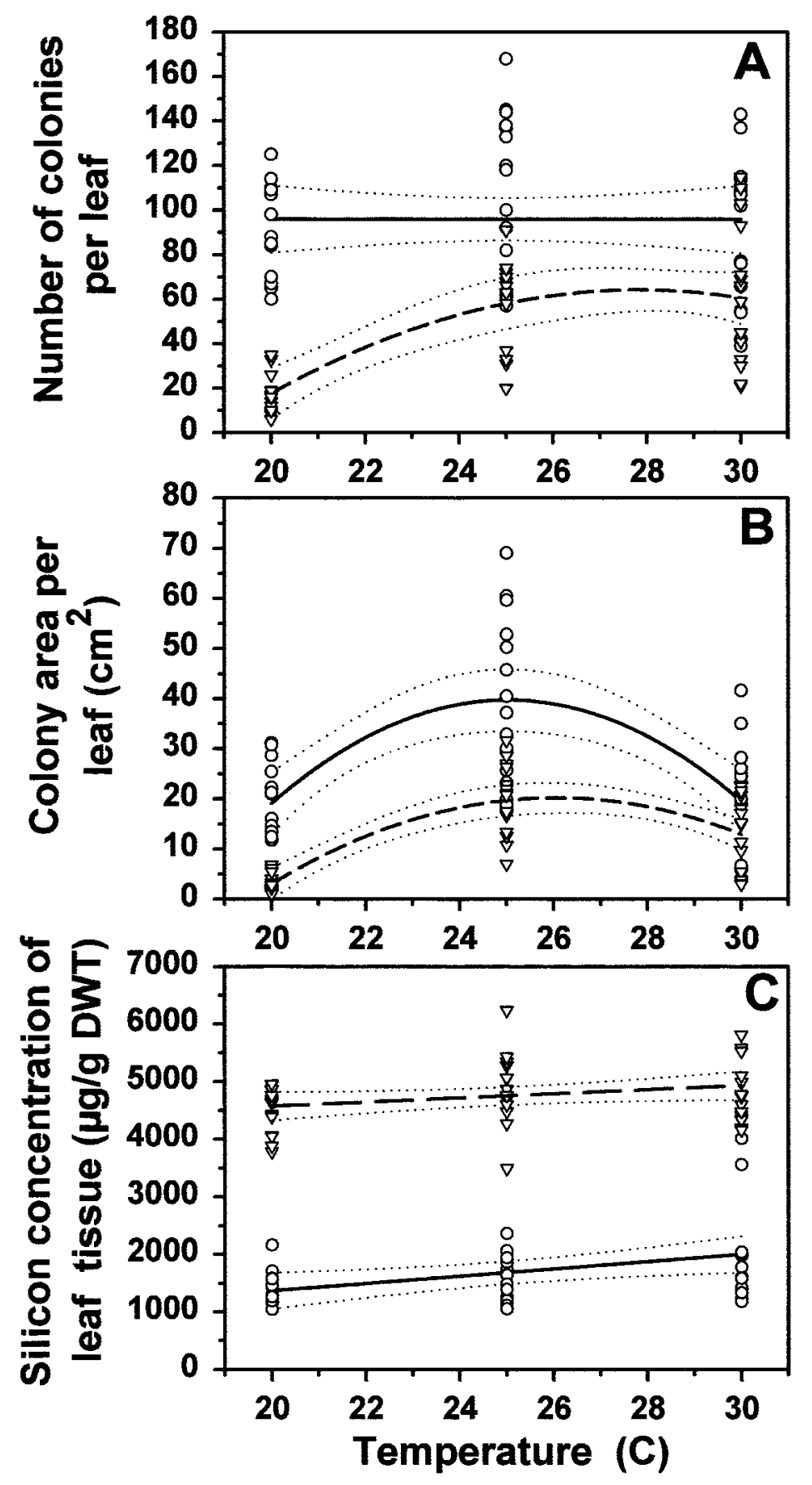

Fig. 4. Effects of temperature on the effectiveness of silicon amendments to suppress powdery mildew (PM) caused by Sphaerotheca fuliginea on cucumber (Cucumis sativus, cv. Corona) plants. Data were analyzed with orthogonal polynomial contrast (CONTRAST statements in PROC GLM) and linear or quadratic regression models (PROC REG or PROC RSREG, respectively). A, Numbers of PM colonies per leaf were significantly lower at $20^{\circ} \mathrm{C}$ than at 25 or $30^{\circ} \mathrm{C}$ for $\mathrm{Si}+$ treated plants irrigated with silicon at $100 \mathrm{mg} /$ liter $(\nabla$; dashed lines) compared with $\mathrm{Si}-$ control plants irrigated with silicon at $0 \mathrm{mg} / \mathrm{liter}\left(\mathrm{O}\right.$; solid lines). [Si- treatment: $y=96-0.013 x ; P>0.10 ; r^{2}<0.001$. Si+ treatment: $y=-525+42 x-0.76 x^{2} ; P<0.01 ; r^{2}=0.449$.] B, Areas of PM per leaf on cucumber plants irrigated with silicon at 0 or $100 \mathrm{mg} /$ liter were described best by quadratic models in which no clear effect of temperature was observed; both treatments were described best by quadratic models. [Si- treatment: $y=-471+41 x-0.82 x^{2} ; P<0.0001 ; r^{2}=0.404$. Si+ treatment: $y=-297+24 x-$ $0.47 x^{2} ; P<0.0001 ; r^{2}=0.575$.] C, Silicon concentrations in cucumber leaves increased slightly with increasing temperatures; responses were described best by linear models. [Si- treatment: $y=103+$ $63 x ; P=0.014 ; r^{2}=0.134 ;$ Si+ treatment: $\left.y=3860+36 x ; P=0.07 ; r^{2}=0.074.\right][n=15 ; 95 \%$ confidence intervals are given for each plot.] 
to $32^{\circ} \mathrm{C}$ in the summer. Thus, we conclude that the difference in average temperatures between greenhouses in Canada and Florida was the likely reason for the reduced suppression of PM on cucumber plants by silicon amendments in Florida.

The mechanism by which lower temperatures increased the effectiveness of silicon amendment for PM suppression is not known. Based on the current study, the answer does not appear to be changes in the concentration of silicon in leaf tissues, because the effects of temperature and shading on silicon content in leaves did not correlate with their effects on PM. During the temperature experiment, silicon concentrations in cucumber leaves for both the $\mathrm{Si}-$ and $\mathrm{Si}+$ treatments increased slightly as temperature increased, which is opposite to the effect of temperature on PM suppression. In addition, during the shading experiment, silicon content decreased significantly in the $\mathrm{Si}+$ irrigated plants as shading increased from 0 to $70 \%$, even though no changes were observed in the number of PM colonies or the area of PM coverage on inoculated leaves. The effects of high temperature and increased shading on silicon concentrations in cucumber leaves are consistent with silicon uptake in plants being nonselective and driven by mass flow of water into plants (7). In general, plants would transpire more water at high temperatures and would transpire less water under low light intensities. Thus, leaf concentrations of silicon would be expected to increase as temperature increased and decrease as shading increased. Silicon has been shown to be present in cell walls and papillae of $C$. sativus during infection by $S$. fuliginea (19), but reductions in fungal colony numbers of PM on cucumber leaves does not appear to be due to direct biocidal effects of silicon on germinating conidia or hyphae of $S$. fuliginea $(2,15,19)$. Our results are consistent with these studies. In both the temperature and shading experiments, the effectiveness of silicon amendments to suppress PM on cucumber did not correlate with changes in silicon concentrations in leaves. Also, there were no significant differences observed between blocks in experiments 1 and 2, which differed primarily in the degree of shading within the research greenhouse. Thus, the mechanism responsible for increased PM suppression by silicon at $20^{\circ} \mathrm{C}$ is other than an accumulation of silicon in leaves.

The process by which silicon may suppress PM disease in cucumber is not clear, although several alternative mechanisms have been proposed. Menzies et al. (15) suggested that $\mathrm{Si}+$ treated cucumber plants deposited high levels of phenolic compounds or lignins at sites of fungal penetration and, thus, increased resistance of host cells to pathogen penetration. Samuels et al. (17) reported that, during infection by $S$. fuliginea on cucumber leaves, areas of host cell walls immediately adjacent to germinating hyphae exhibited altered surface textures and high concentrations of silicon. It was suggested that deposition of silicon at sites of infection might be a factor in PM suppression by silicon (17). In addition, Fawe et al. (8) reported the production of a new fungitoxic compound (a flavonol phytoalexin) in cucumber leaves that was stimulated by silicon amendment that may have been responsible for suppressing PM. Although the results from the current study do not clarify the mechanism of PM suppression by silicon in cucumber, the role of temperature on disease suppression of PM by silicon might provide a means to explore the disease suppression mechanism further. If one or more of the mechanisms can be shown to correlate directly with changes in PM suppression as temperature is altered, then the primary factors in the disease suppression process induced by silicon might be identified. For example, lignin and phenolic acids deposited in leaf and bark tissues of several plant species generally increase as temperature increases $(1,6,9)$. If a similar effect of high temperature on lignin deposition can be demonstrated for cucumber while PM resistance induced by silicon amendment is shown to decrease at high temperature, then a direct role of lignin on PM suppression in cucumber irrigated with silicon (15) may be in question.

The results reported here confirm other studies $(2,14,17)$ which demonstrated that silicon amendments to plant nutrient solutions are generally benign and in which minor phenotypic alterations of plant growth and development occurred. Other studies $(7,12)$ have suggested that silicon amendments to nutrient solutions can act to promote growth in hydroponically grown plants like tomato, rose, and cucumber. In experiments 1 and 2, all plant morphological parameters measured exhibited no changes in $\mathrm{Si}+$ compared with $\mathrm{Si}$ - treated plants. The only observed difference in $\mathrm{Si}+$ compared with $\mathrm{Si}$ - treated plants was the observation of white powdery secretions associated with trichomes on periderm tissues of $\mathrm{Si}+$ treated cucumber fruit. This has been observed previously for silicontreated cucumber fruit (17). In addition, the leaf curl, stunting, and leaf chlorosis on cucumber leaves grown in low-silicon nutrient solutions reported by Marschner et al. (12) were not observed in our study with silicon-deficient cucumber plants. This may be due to higher zinc concentrations used here (Table 1) compared with Marschner et al. (12); stunting and chlorosis in low-silicon nutrient solutions can be reduced by increasing zinc concentrations delivered to cucumber plants (12). The lack of plant stunting observed for $\mathrm{Si}$ - treated plants in the current study also may be due to the presence of silicon at $10 \mathrm{mg} / \mathrm{liter}$ in the source water used to prepare all nutrient solutions. In all cases in which cucumber leaves were analyzed for silicon content, the $\mathrm{Si}$ - treated plants were found to possess $>1,000 \mu \mathrm{g} / \mathrm{g}$ dry weight of silicon.

The average silicon level in cucumber fruit irrigated with potassium silicate $(2,100 \mu \mathrm{g} / \mathrm{g}$ dry weight) was similar to the average silicon level found in store-bought field-grown cucumber $(1,678 \mu \mathrm{g} / \mathrm{g}$ dry weight). In contrast, the average silicon content in fruit irrigated with $\mathrm{Si}$ - nutrient solution was $659 \mu \mathrm{g} / \mathrm{g}$ dry weight. Thus, silicon levels in cucumbers grown in $\mathrm{Si}+$ nutrient solutions might be comparable to field-grown cucumbers ingested by the average consumer. High levels of silicon detected in unwashed periderm tissues $(2,700 \mu \mathrm{g} / \mathrm{g}$ dry weight) may be explicable based on the results of Samuels et al. (18), who reported that cucumber fruit irrigated with $\mathrm{Si}+$ nutrient solutions possessed deposits of silicon crystals at trichome bases. In the current study, cucumber fruit grown at elevated levels of silicon exhibited white, powdery residues on surfaces of periderm tissues. Thus, as long as cucumber fruit irrigated with supplemental silicon are washed prior to consumption, the high silicon content of periderm tissues should be easily removed. Results from measurements on the effects of silicon on plant growth and on the concentration of silicon in cucumber fruit support the conclusions of Epstein (7) that hydroponically grown cucumber plants irrigated with silicon-free nutrient solutions probably constitute growing environments that are atypical of field-grown agricultural systems. This is supported further by the fact that silicon is the second most abundant element in soil, and is readily assimilated by plants (7). The results reported here suggest that the addition of potassium silicate to hydroponic nutrient solutions does not excessively elevate silicon concentration in cucumber.

In conclusion, although silicon has worked elsewhere for suppressing PM on cucumber plants $(2,13-15,17,19)$, the results of the current study in Florida indicate that silicon may not work effectively for PM suppression on cucumber leaves at high temperatures $\left(24\right.$ to $\left.32^{\circ} \mathrm{C}\right)$. Additional tests with other plant species, pathogens, horticultural practices, and agricultural systems should be explored to determine if temperature plays a significant role in the effectiveness of silicon disease suppression in other pathosystems. For example, applications of silicon fertilizers have been shown to successfully reduce rice blast in warm semitropical and tropical climates $(5,20,21)$. Thus, the effects of high temperatures in reducing the effectiveness of silicon amendments for PM suppression reported here may occur only in greenhouse-grown cucumber. We also conclude that additions of silicon to nutrient solutions have no apparent detrimen- 
tal effects on cucumber plants, and do not excessively increase concentrations of silicon in harvested cucumber fruit.

\section{ACKNOWLEDGMENTS}

We thank Julie Pepe (Department of Statistics, University of Central Florida, Orlando) and Steve Linda (IFAS Statistics Department, University of Florida, Gainesville) for their assistance in the statistical analysis of experimental data; James G. Menzies (Agriculture Canada Research Station, Agassiz, BC, Canada) and Richard R. Belanger (University of Laval, Quebec, Canada) for their suggestions during the early phases in developing this research; and J. Menzies for supplying the Canadian sawdust for experiment 2 .

\section{LITERATURE CITED}

1. Akin, D. E., Fales, S. L., Rigsby, L. L., and Snook, M. E. 1987. Temperature effects on leaf anatomy, phenolic acids, and tissue digestibility in tall fescue. Agron. J. 79:271275.

2. Bélanger, R. R., Bowen, P. A., Ehret, D. L., and Menzies, J. G. 1995. Soluble silicon: Its role in crop and disease management of greenhouse crops. Plant Dis. 79:329-336.

3. Bélanger, R. R., Dik, A. J., and Menzies, J. G. 1992. Powdery mildews: Recent advances toward integrated control. Pages 89-109 in: PlantMicrobe Interactions and Biological Control. G. J. Boland and L. D. Kuykendall, eds. Marcel Dekker, Inc. Publishers, New York.

4. Carnelli, A. L., Madella, M., and Theurillat, J. P. 2001. Biogenic silica production in selected alpine plant species and plant communities. Ann. Bot. 87:425-434

5. Datnoff, L. E., Snyder, G. H., and Korndörfer, G. H. 2001. Silicon in Agriculture. Elsevier
Science B. V., Amsterdam, The Netherlands.

6. Doster, M. A., and Bostock, R. M. 1988. Effects of low temperature on resistance of almond trees to Phytophthora pruning wound cankers in relation to lignin and suberin formation in wounded bark tissues. Phytopathology 78:478-483.

7. Epstein, E. 1994. The anomaly of silicon in plant biology. Proc. Natl. Acad. Sci. USA 91:11-17.

8. Fawe, A., Abou-Zaid, M., Menzies, J. G., and Bélanger, R. R. 1998. Silicon-mediated accumulation of flavonoid phytoalexins in cucumber. Phytopathology 88:396-401.

9. Ford, C. W., Morrison, I. M., and Wilson, J. R. 1979. Temperature effects on lignin, hemicellulose and cellulose in tropical and temperate grasses. Aust. J. Agric. Res. 30:621-633.

10. Jarvis, W. R. 1992. Managing Diseases in Greenhouse Crops. American Phytopathological Society Press, St. Paul, MN

11. Lewin, J., and Reiman, B. E. F. 1969. Silicon and plant growth. Annu. Rev. Plant Physiol. 20:289-304.

12. Marschner, H., Oberle, H., Cakmak, I., and Romheld, V. 1990. Growth enhancement by silicon in cucumber (Cucumis sativus) plants depends on imbalance in phosphorous and zinc supply. Plant Soil 124:211-219.

13. Menzies, J. G., Bowen, P. Ehret, D., and Glass, D. M. 1992. Foliar applications of potassium silicate reduce severity of powdery mildew on cucumber, muskmelon, and zucchini squash. J. Am. Soc. Hortic. Sci. 117:902-905.

14. Menzies, J. G., Ehret, D. L., Glass, A. D. M., Helmer, T., Koch, C., and Seywerd, F. 1991. Effects of soluble silicon on the parasitic fitness of Sphaerotheca fuliginea on Cucumis sativus. Phytopathology 81:84-88.

15. Menzies, J. G., Ehret, D. L., Glass, A. D. M. and Samuels, A. L. 1991. The influence of silicon on cytological interactions between Sphaerotheca fuliginea and Cucumis sativus. Physiol. Mol. Plant Physiol. 39:403-414.

16. Miyake, Y., and Takahashi, E. 1983. Effect of silicon on the growth of solution-cultured cucumber plant. Soil Sci. Plant Nutr. 29:71-83.

17. Samuels, A. L., Glass, A. D. M., Ehret, D. L. and Menzies, J. G. 1991. Distribution of silicon in cucumber leaves during infection by powdery mildew fungus (Sphaerotheca fuliginea). Can. J. Bot. 69:140-146.

18. Samuels, A. L., Glass, A. D. M., Ehret, D. L., and Menzies, J. G. 1993. The effects of silicon supplementation on cucumber fruit: Changes in surface characteristics. Ann. Bot. 72:433-440.

19. Samuels, A. L., Glass, A. D. M., Menzies, J. G., and Ehret, D. L. 1994. Silicon in cell walls and papillae of Cucumis sativus during infection by Sphaerotheca fuliginea. Physiol. Mol. Plant Physiol. 44:237-242.

20. Seebold, K. W., Datnoff, L. E., Correa-Victoria, F. J., Kucharek, T. A., and Snyder, G. H 2000. Effect of silicon rate and host resistance on blast, scald, and yield of upland rice. Plant Dis. 84:871-876.

21. Seebold, K. W., Kucharek, T. A., Datnoff, L. E., Correa-Victoria, F. J., and Marchetti, M. A. 2001. The influence of silicon on components of resistance to blast in susceptible, partially resistant, and resistant cultivars of rice. Phytopathology 91:63-69.

22. Wagner, H. K. 1940. Die Bedeutung der Kieselsäure für das Wachstrum einiger Kulturpflanzen, irhren Nährstoffhaushalt und ihre Anfälligkeit gegen echte Mehltaupilze. Phytopathol. Z. 12:427-479. 